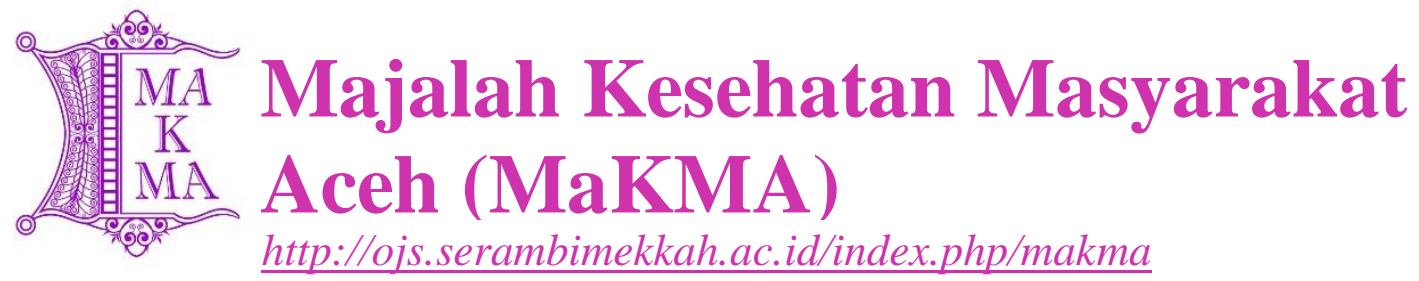

\title{
PENGARUH KEPATUHAN IBU HAMIL DALAM MENGKONSUMSI TABLET ZAT BESI DI WILAYAH KERJA PUSKESMAS MUARA DUA KOTA LHOKSEUMAWE
}

\author{
Anita Marlina \\ Mahasiswa Magister Kesehatan Masyarakat Unsyiah
}

\begin{abstract}
${ }^{\otimes}$ Alamat Korespondensi: Los F No. 25 Kelurahan Kota Lhokseumawe Kecamatan Banda Sakti. Email: anitaamalia34@gmail.com. Hp.082363244463
\end{abstract}

\begin{abstract}
ABSTRAK
Berdasarkan data World Health Organization (WHO) 2005, kejadian anemiapada ibu hamil setiap tahunnya tahunnya mencapai lebih dari 500.000 orang. Laporan dari Dunia menyebutkan bahwa frekuensi anemia dalam kehamilan cukup tinggi, terutama di Negara-negara berkembang berkisar 10-22\%. Menurut data dari Dinas Kesehatan Nanggroe Aceh Darussalam, jumlah ibu hamil di wilayah Kota Lhokseumawe sebesar 4.253 jiwa, sedangkan ibu hamil yang anemia sebesar 154 jiwa (3,62 \%). Dari hasil penelitian dari beberapa puskesmas di wilayah Kota Lhokseumawe, bahwa Puskesmas Muara Dua yang masih banyak ibu hamil yang mengalami Anemia. Berdasarkan data Puskesmas Muara dua Kota Lhokseumawe jumlah ibu hamil 1.786 jiwa dan ibu hamil yang mengalami anemia sebesar 57 orang $(3,19 \%)$. Penelitian ini bertujuan Untuk mendapat gambaran Faktor-Faktor Yang Mempengaruhi Kepatuhan Ibu Hamil Dalam Mengkonsumsi Tablet Zat Besi Di Wilayah Kerja Puskesmas Muara Dua Kota Lhokseumawe. Jenis penelitian ini adalah penelitian metode survei Analitik dengan pendekatan Cross Sectional Study, populasi dalam penelitian ini ibu hamil yang berada dalam Wilayah kerja Puskesmas Muara Dua Kota Lhokseumawe, yaitu berjumlah 72 orang. Sampel dalam penelitian ini adalah ibu hamil yang berada diwilayah Puskesmas Muara Dua, dan pernah mendapatkan tablet besi. Teknik yang dipakai dalam penelitian ini adalah purposive sampling dengan menggunakan kriteria inklusi. Analisis data menggunakan uji Chi-square Test dengan kemaknaan $95 \%$. Hasil Penelitian menunjukkan frekuensi usia dengan kepatuhan berada pada kategori reproduksi sehat (72,2\%), frekuensi pekerjaan dengan kepatuhan berada pada kategori tidak bekerja $(65,3 \%)$, frekuensi pengetahuan dengan kepatuhan berada pada kategori cukup (75\%). Ini menunjukkan ada hubungan antara usia, pekerjaan, dan pengetahuan. Kesimpulan hasil uji statistik Chi-square diketahui nilai tersebut lebih kecil dari alpha $(\mathrm{p} \leq 0,05)$, maka Ha diterima.
\end{abstract}

Kata Kunci : Ibu Hamil, Kepatuhan, Zat Besi.

Riwayat Artikel

Diterima : : 14 Januari 2019 


\title{
THE EFFECT OF PREGNANT WOMEN'S COMPLIANCE IN CONSUMING IRON TABLETS IN THE WORKING AREA OF PUSKESMAS MUARA DUA KOTA LHOKSEUMAWE
}

\begin{abstract}
Based on data from the World Health Organization (WHO) 2005, the incidence of anemia in pregnant women annually reaches more than 500,000 people. Reports from the World state that the frequency of anemia in pregnancy is quite high, especially in developing countries ranging from 10-22\%. According to data from the Nanggroe Aceh Darussalam Health Office, the number of pregnant women in the Lhokseumawe City area was 4,253 people, while anemic pregnant women were 154 people (3.62\%). From the results of research from several health centers in the Lhokseumawe City area, that Muara Dua Health Center still has many pregnant women who experience anemia. Based on data from Muara Dua Health Center in Lhokseumawe City, the number of pregnant women was 1,786 people and pregnant women who had anemia were 57 people (3.19\%). Research Objective: aims to get an overview of the Factors Affecting the Compliance of Pregnant Women in Consuming Iron Tablets in the Work Area of Muara Dua Health Center, Lhokseumawe City. Research Method This type of research is Analytical survey method with Cross Sectional Study approach, the population in this study were pregnant women who were in the work area of Muara Dua Health Center in Lhokseumawe City, which amounted to 72 people. The sample in this study were pregnant women in the Muara Dua Health Center area, and had received iron tablets. The technique used in this study was purposive sampling using inclusion criteria. Analysis To test the hypothesis using the Chi-square Test with 95\% significance. Results the frequency of age with adherence was in the category of healthy reproduction $(72.2 \%)$, the frequency of work with compliance was in the category of not working $(65.3 \%)$, frequency of knowledge with compliance was in the sufficient category (75\%). This shows there is a relationship between age, work, and knowledge. The conclusion of the results of the Chi-square statistical test is that the value is smaller than alpha (p 5 0.05), then Ha is accepted.
\end{abstract}

Keywords: Pregnant Women, Compliance, Iron. 


\section{PENDAHULUAN}

Anemia merupakan masalah kesehatan yang memerlukan perhatian di seluruh dunia, karena menyebabkan gangguan selama hamil dan persalinan, berbahaya bagi janin seperti bayi lahir prematur atau lahir dengan cadangan zat besi yang kurang. Pada acuan nasional pelayanan kesehatan maternal dan neonatal (2001) disebutkan frekuensi ibu hamil dengan anemia di Indonesia sekitar 63,5 \%. dan Sampai saat ini tingginya angka kematian ibu di Indonesia masih merupakan masalah yang menjadi prioritas di bidang kesehatan, karena Penyebab langsung kematian ibu salah satunya yaitu perdarahan pada saat persalinan ${ }^{[1]}$.

Berdasarkan data World Health Organization (WHO), kejadian anemia pada ibu hamil setiap tahunnya tahunnya mencapai lebih dari 500.000 orang. Laporan dari Dunia menyebutkan bahwa frekuensi anemia dalam kehamilan cukup tinggi, terutama di Negara-negara berkembang berkisar 10-22\%. pemberian tablet zat besi merupakan upaya mencegah terjadinya anemia pada masa kehamilan. Mengingat prevalensi anemia gizi cukup tinggi pada ibu hamil ,maka pemerintah berupaya melakukan intervensi, salah satunya dengan pemberian suplementasi zat besi ${ }^{[2]}$.

Walaupun rata-rata ibu hamil telah mendapatkan tablet zat besi, namun pada kenyataannya angka kejadian anemia pada ibu hamil di wilayah Muara Dua Kota Lhokseumawe masih tinggi, yang disebabkan karena konsumsi tablet zat besi tidak teratur atau tidak habis dikosumsi oleh ibu hamil sehingga kemungkinan banyak faktor-faktor yang menyebabkannya seperti faktor pengetahuan, umur ibu, dan pekerjaan,
Oleh karena itu, perlu dilakukan suatu pengkajian dan analisa terhadap kepatuhan ibu hamil dalam mengkonsumsi tablet zat besi yang sesuai dengan petunjuk dari petugas kesehatan, sehingga akan terbukti hubungan antara keteraturan dalam mengkonsumsi tablet zat besi dengan angka kejadian anemia dalam kehamilan $^{[1]}$.

Kepatuhan didefinisikan sebagai sejauhmana prilaku pasien sesuai dengan ketentuan yang diberikan oleh profesional kesehatan. Zat besi yang dibutuhkan yaitu 90 tablet selama kehamilan yang mengandung $60 \mathrm{mg}$ zat besi. tapi sering kali ibu hamil tidak mematuhi tujuan atau melupakan begitu saja atau salah instruksi yang diberikan $^{[2]}$.

Ketidakpatuhan telah menjadi suatu masalah serius yang dihadapi tenaga kesehatan. Oleh karena itu penting untuk diketahui tentang tingkat ketidakpatuhan. Pengkajian yang akurat terhadap individu yang tidak patuh merupakan suatu tugas yang sulit. Kasl dalam Niven mengungkapkan bahwa untuk mengukur ketidakpatuhan ibu hamil dapat dilihat dari tablet zat besi yang diberikan tidak dihabiskan ${ }^{[3]}$.

Menurut data dari Dinas Kesehatan Nanggroe Aceh Darussalam (Dinkesnad) tahun 2008 dalam wilayah Kota Lhokseumawe jumlah ibu hamil sebesar 4.253 jiwa, sedangkan ibu hamil yang anemia sebesar 154 jiwa (3,62\%). Puskesmas Muara Dua yang masih banyak ibu hamil yang mengalami Anemia. Data yang didapatkan di Puskesmas Muara Dua Kota lhokseumawe tahun 2008 jumlah ibu hamil 1.786 jiwa dan ibu hamil yang mengalami anemia sebesar 57 orang 
(3,19\%). Berdasarkan hasil survey, data yang didapatkan bahwa jumlah ibu hamil di Puskesmas Muara Dua sebanyak 991 jiwa.

Berdasarkan dari uraian diatas, maka penulis tertarik untuk meneliti lebih lanjut tentang "Faktor-Faktor Yang

\section{METODE}

Jenis penelitian ini adalah penelitian metode survei Analitik dengan pendekatan Cross Sectional Study, populasi dalam penelitian ini ibu hamil yang berada dalam Wilayah kerja Puskesmas Muara Dua Kota Lhokseumawe, yaitu berjumlah 72

\section{HASIL}

Berdasarkan hasil penelitian yang telah dilakukan dari tanggal 11 Januari sampai dengan 16 Januari 2010 di Wilayah Kerja Puskesmas Muara Dua terhadap 72 responden, dengan menggunakan Analisa Univariat dan Analisa Bivariat.

Analisa Univariat untuk melihat distribusi frekuensi dari variabel dependen (terikat) yaitu Kepatuhan Ibu Hamil Dalam Mengkonsumsi Tablet Zat Besi dan variabel independen (bebas) yang meliputi Usia ibu, pekerjaan, dan Kepatuhan. Berdasarkan [Tabel.1] diketahui bahwa diketahui bahwa Pengetahuan ibu hamil dalam mengkonsumsi tablet zat besi di Wilayah Puskesmas Muara Dua sebagian besar responden berada dalam kategori cukup yaitu sebanyak 44 orang $(61,1 \%)$.

Analisa Bivariat digunakan untuk mengetahui ada tidaknya hubungan antara variabel dependen dengan variabel independen. Untuk pengujian dalam penelitian ini menggunakan program SPPS Versi 17.00.
Mempengaruhi Kepatuhan Ibu Hamil Dalam Mengkonsumsi Tablet Zat Besi Di Wilayah Kerja Puskesmas Muara Dua Kota Lhokseumawe 2009".

orang. Sampel dalam penelitian ini adalah ibu hamil yang berada diwilayah Puskesmas Muara Dua, dan pernah mendapatkan tablet besi. Teknik yang dipakai dalam penelitian ini adalah purposive sampling dengan menggunakan kriteria inklusi.

Berdasarkan [Tabel.2] diketahui bahwa dari 52 responden yang reproduksi sehat ternyata $63,9 \%$ patuh dan $8,3 \%$ tidak patuh, dari 20 responden yang resiko tua ternyata patuh dan tidak patuh ternyata $13,9 \%$. Hasil analisa statistik menggunakan uji chi square menunjukkan pengaruh tersebut bermakna, dimana nilai $\mathrm{p}$ value $0,01(\mathrm{P}$ $\leq 0,05)$. Hal tersebut berarti hipotesis penelitian yang menyatakan ada pengaruh antara usia dengan kepatuhan terbukti dan dapat diterima.

Berdasarkan [Tabel.3] diketahui bahwa dari 25 responden yang bekerja ternyata $19,4 \%$ patuh dan $15,3 \%$ tidak patuh, dari 47 responden yang tidak bekerja ternyata $58,3 \%$ patuh dan $6,9 \%$ tidak patuh. Hasil analisa statistik menggunakan uji chi square menunjukkan pengaruh tersebut bermakna, dimana nilai $\mathrm{p}$ value $0,03(\mathrm{P} \leq$ 0,05). Hal tersebut berarti hipotesis penelitian yang menyatakan ada pengaruh antara pekerjaan dengan kepatuhan terbukti dan dapat diterima.

Berdasarkan [Tabel.4] diketahui bahwa dari 54 responden yang 
pengetahuan cukup ternyata $66,7 \%$ patuh dan 8,3\% tidak patuh, dari 18 responden pengetahuan kurang ternyata $11,1 \%$ patuh dan $13,9 \%$ tidak patuh. Hasil analisa statistik menggunakan uji chi square menunjukkan pengaruh

\section{PEMBAHASAN}

Dari uraian di atas dapat disimpulkan bahwa usia ibu reproduksi sehat mayoritas $8,3 \%$ yang tidak patuh. Ini sangat berpengaruh terhadap kemauan dan kesadaran ibu untuk mengkonsumsi tablet zat besi.

Hal ini sesuai dengan pendapat Notoadmodjo, bahwa usia juga berpengaruh terhadap psikis seseorang, seperti usia muda sering menimbulkan ketegangan, kebingungan, rasa cemas dan rasa takut sehingga dapat berpengaruh terhadap tingkah lakunya. Semakin bertambah usia maka semakin bertambah pengalaman yang diperolehnya, sehingga seseorang dapat meningkatkan kematangan mental dan intelektual sehingga dapat membuat keputusan yang lebih bijaksana dalam bertindak $^{[3]}$.

Ibu yang tidak bekerja mayoritas $6,9 \%$ tidak patuh. Ini sangat berpengaruh terhadap kemauan ibu untuk mengkonsumsi tablet zat besi. Hal ini sesuai dengan pendapat Litbangkes, Bekerja yaitu kegiatan yang dapat menghasilkan uang dari perkerjaan sebagai PNS atau pegawai badan usaha milik negara (BUMN), wiraswasta atau buruh. Sedangkan tidak bekerja yaitu sesuatu yang tidak dapat menghasilkan uang $^{[5]}$.

Tingkat pengetahuan ibu untuk mengetahui gambaran faktor pengetahuan yang dimiliki ibu sehingga ibu mempunyai kemauan untuk mengkonsumsi tablet zat besi. Dan dengan adanya pengetahuan tentang tersebut bermakna, dimana nilai $\mathrm{p}$ value $0,00$ ( $\mathrm{P} \leq 0,05)$. Hal tersebut berarti hipotesis penelitian yang menyatakan ada pengaruh antara pengetahuan dengan kepatuhan terbukti dan dapat diterima.

pentingnya tablet zat besi selama kehamilan maka usaha ibu untuk mengkonsumsi tablet zat besi akan berhasil dan lebih patuh karena ditunjang dengan kepatuhan ibu yang lebih baik. Hal ini sesuai dengan pendapat Menurut Notoadmodjo, pengetahuan adalah hasil dari tahu dan ini terjadi setelah orang melakukan pengindraan terhadap suatu objek tertentu. Pengindraan terjadi melalui pancaindra manusia, yakni indra penglihatan, pendengaran, penciuman, rasa dan raba. Sebagian besar pengetahuan manusia diperoleh melalui mata dan telinga ${ }^{[3]}$.

Menurut asumsi peneliti Ada berbagai faktor yang mempengaruhi perilaku sehat seseorang selain pengetahuan, seperti pengalaman, keyakinan, informasi dan komunikasi juga mempengaruhi perilaku seseorang. Pengalaman atau riwayat penyakit sebelumnya yang pernah dialami individu dapat mempengaruhinya dalam berperilaku. Keyakinan atau nilai yang dipegang seseorang yang berhubungan dengan kesehatan akan mempengaruhinya dalam berperilaku sehat. Hal inilah salah satu hal yang menyebabkan ibu hamil di wilayah kerja puskesmas muara dua khususnya mayoritas patuh meski pengetahuan yang mereka miliki berada pada kategori cukup. 


\section{KESIMPULAN DAN SARAN}

Hasil Penelitian menunjukkan frekuensi usia dengan kepatuhan berada pada kategori reproduksi sehat $(72,2 \%)$, frekuensi pekerjaan dengan kepatuhan berada pada kategori tidak bekerja $(65,3 \%)$, frekuensi pengetahuan dengan

\section{DAFTAR PUSTAKA}

1. Dinkes Kota Lhokseumawe, 2008, Data Rekap laporan_Tahun 2008

2. Jordan, Sue, 2004. Farmakologi Kebidanan, Monica Ester, Jakarta

3. Litbangkes. 2005. Penelitian Kesehatan. Jakarta. kepatuhan berada pada kategori cukup $(75 \%)$. Ini menunjukkan ada hubungan antara usia, pekerjaan, dan pengetahuan.

Diharapkan kepada ibu hamil untuk terus meningkatkan pengetahuan mengenai Tablet Zat Besi, terutama mengenai cara mengkonsumsi tablet zat besi yang benar.

4. World Health Organization (WHO).

Maternal Mortality in 2005. Geneva :

Departement of Reproductive Health and Researh

5. Prawirohardjo, S 2003. Pendidikan dan Prilaku Kesehatan. Rineka cipta, Jakarta. 


\section{LAMPIRAN}

[Tabel.1]. Distribusi Frekuensi Responden Berdasarkan Pengetahuan Ibu Di Wilayah Kerja Puskesmas Muara Dua

\begin{tabular}{lccc}
\hline & Pengetahuan Ibu & Frekuensi & \% \\
\hline Baik & 10 & 13,9 \\
Cukup & 44 & 61,1 \\
Kurang & & 18 & 25,0 \\
\hline & Jumlah & $\mathbf{7 2}$ & $\mathbf{1 0 0}$ \\
\hline
\end{tabular}

[Tabel.2]. Pengaruh Usia Dengan Kepatuhan Di Wilayah Kerja Puskesmas Muara Dua

\begin{tabular}{|c|c|c|c|c|c|c|c|}
\hline \multirow{3}{*}{ Usia } & \multicolumn{4}{|c|}{ Kepatuhan } & \multirow{2}{*}{\multicolumn{2}{|c|}{ Total }} & \multirow{3}{*}{$\begin{array}{c}\mathbf{P} \\
\text { Value }\end{array}$} \\
\hline & \multicolumn{2}{|c|}{ Patuh } & \multicolumn{2}{|c|}{$\begin{array}{l}\text { Tidak } \\
\text { Patuh }\end{array}$} & & & \\
\hline & $\mathbf{f}$ & $\%$ & $\mathbf{F}$ & $\%$ & $\mathbf{F}$ & $\%$ & \\
\hline Reproduksi Sehat & 46 & 63,9 & 6 & 8,3 & 52 & 72,2 & $\mathbf{0 , 0 1}$ \\
\hline Resiko Tua & 10 & 13,9 & 10 & 13,9 & 20 & 27,8 & \\
\hline Jumlah & 56 & 77,8 & 16 & 22,2 & 72 & 100 & \\
\hline
\end{tabular}

Signifikan $\mathrm{P} \leq 0,05$

[Tabel.3]. Pengaruh Pekerjaan Dengan Kepatuhan Di Wilayah Kerja Puskesmas Muara Dua

\begin{tabular}{lcccccccc}
\hline \multirow{2}{*}{ Pekerjaan } & \multicolumn{3}{c}{ Kepatuhan } & Total & $\begin{array}{c}\text { P } \\
\text { Value }\end{array}$ \\
\cline { 2 - 9 } & \multicolumn{2}{c}{ Patuh } & \multicolumn{2}{c}{ Tidak } & & & \\
\cline { 2 - 9 } Bekerja & 14 & 19,4 & 11 & 15,3 & 25 & 34,7 & $\mathbf{0 , 0 3}$ \\
Tidak Bekerja & 42 & 58,3 & 5 & 6,9 & 47 & 65,3 & \\
\hline Jumlah & $\mathbf{5 6}$ & $\mathbf{7 7 , 7}$ & $\mathbf{1 6}$ & $\mathbf{2 2 , 2}$ & $\mathbf{7 2}$ & $\mathbf{1 0 0}$ & \\
\hline
\end{tabular}

Signifikan $\mathrm{P} \leq 0,05$ 
Tabel [4]. Pengaruh Usia Dengan Kepatuhan Di Wilayah Kerja Puskesmas Muara Dua

\begin{tabular}{lccccccc}
\hline \multirow{2}{*}{ Pengetahuan } & \multicolumn{3}{c}{ Kepatuhan } & Total & $\begin{array}{c}\text { P } \\
\text { Value }\end{array}$ \\
& \multicolumn{9}{c}{ Patuh } & \multicolumn{9}{c}{$\begin{array}{c}\text { Tidak } \\
\text { Patuh }\end{array}$} \\
\cline { 2 - 9 } Cukup & $\mathbf{f}$ & $\mathbf{\%}$ & $\mathbf{f}$ & $\mathbf{\%}$ & $\mathbf{F}$ & $\mathbf{\%}$ & \\
Kurang & 48 & 66,7 & 6 & 8,3 & 54 & 75 & $\mathbf{0 , 0 0}$ \\
\hline Jumlah & 8 & 11,1 & 10 & 13,9 & 18 & 25 & \\
& $\mathbf{5 6}$ & $\mathbf{7 7 , 8}$ & $\mathbf{1 6}$ & $\mathbf{2 2 , 2}$ & $\mathbf{7 2}$ & $\mathbf{1 0 0}$ & \\
\hline
\end{tabular}

Signifikan $P \leq 0,05$ 